\title{
The Relationship between a Night Usage of Mobile Phone and Sleep Habit and the Circadian Typology of Japanese Students Aged 18 - 30 yrs
}

\author{
Takahiro Kawada ${ }^{1}$, Tetsuro Kataoka ${ }^{2}$, Fujiko Tsuji ${ }^{2}$, Miyo Nakade ${ }^{3}$, Milada Krejci ${ }^{4}$, Teruki Noji ${ }^{1}$, \\ Hitomi Takeuchi ${ }^{2}$, Tetsuo Harada ${ }^{2 *}$ \\ ${ }^{1}$ Center for Regional Collaboration, Kochi University, Kochi, Japan \\ ${ }^{2}$ Laboratory of Environmental Physiology, Graduate School of Integrated Arts and Sciences, Kochi University, Kochi, Japan \\ ${ }^{3}$ Faculty of Health and Nutrition, Tokai-Gakuen University, Nagoya, Japan \\ ${ }^{4}$ University of Physical Education and Sports Palestra, Prague, Czech Republic \\ Email: ^haratets@kochi-u.ac.jp
}

How to cite this paper: Kawada, T., Kataoka, T., Tsuji, F., Nakade, M., Krejci, M., Noji, T., Takeuchi, H., \& Harada, T. (2017). The Relationship between a Night Usage of Mobile Phone and Sleep Habit and the Circadian Typology of Japanese Students Aged 18 - 30 yrs. Psychology, 8, 892-902.

https://doi.org/10.4236/psych.2017.86058

Received: January 10, 2017

Accepted: April 27, 2017

Published: April 30, 2017

Copyright () 2017 by authors and Scientific Research Publishing Inc. This work is licensed under the Creative Commons Attribution International License (CC BY 4.0).

http://creativecommons.org/licenses/by/4.0/

\begin{abstract}
This study tries to investigate the current relationship between the habit to use mobile phone and the diurnal type scale and sleep habit in Japanese students. An integrated questionnaire was administered to 555 students aged 18 - 30 years old attending university and medical training schools for physical therapists and medical nurses (average age: $19.8 \pm 1.6$ years) in 2015. Integrated questionnaire included questions on sleep habits, the circadian typology, mental health (out of emotion-control, anger, irritation, depression), meal habits, the diurnal type scale (Torsvall \& Åkerstedt, 1980). Most of all students have their own mobile phones and $96 \%$ of their phones are "smart phones". Two hundreds and twenty four students of 531 ones used their phones within 30 min per one usage, whereas 180 students used it $5-6$ hours per one. There have been significantly no differences in the diurnal type scale scores due to the durations of usage per one usage. Students who put their own mobile phones near to their body during night sleep occupied 461 of 543 students, and they were much more evening-typed than those who put their mobile phones at places far from bed in the same room $(p<0.001)$. In the cases when night sleep would almost start, phone calls could come from some person, 102 students of 537 ones soon responded to it, whereas 200 ones checked the call but did not respond and felt in sleep. These 302 students were much more evening-typed than 230 students who did not mention this call without checking it and felt in sleep $(p<0.001)$. The usual life by the students aged 18 30 years seems to depend on the usage of smart phones very strictly and may strongly relate to sleep habits and also night usage of smart phones are possible to enhance the evening-typed life.
\end{abstract}




\section{Keywords}

Night Usage, Smart Phone, Sleep Habits, Circadian Typology, Mental Health, Japanese Students Aged 18 - 30 Years

\section{Introduction}

Research has emerged daily on cell phone (smart phone use) as follows.

1) Mobile phone usage was reported to reduce academic performance ( $\mathrm{Li}$ et al., 2015). Li et al. (2015) reported that under graduate students $(n=516)$ participated in the study by competing the validated surveys assessing their cell phone use, locus of control, sleep quality, academic performance, and reduced subjective well-being. This study suggested that using the cell phone at bed time was negatively related to sleep quality and that using the cell phone in class and while studying was negatively related to academic performance. 2) Poor sleep quality (Fossum et al., 2014; Li et al., 2015; Exelmans \& Van den Bulk, 2016). Fossum et al. (2014) investigated whether the use of a television, computer, gaming console, tablet, mobile phone, or audio player in bed before going to sleep was associated with insomnia, daytime sleepiness, morningness, or chronotype on 532 students aged 18 - 39. The results showed that mobile phone usage for playing/surfing/texting was positively associated with insomnia and negatively associated with morningness. 3) Decreased mental health (Beranuy et al., 2009). Beranuy et al. (2009) reported that the maladaptive use of the internet and the mobile phone and its relationship to symptoms of psychological distress and mental disorder. Results showed that psychological distress is related to maladaptive use of both the internet and the mobile phone; females scored higher than males on the mobile phone questionnaire, showing more negative consequences of its maladaptive use. 4) Increased sedentary behavior, decreased cardiovascular fitness and decreased intensity of planned exercise (Lepp et al., 2013; Rebold et al., 2015). Lepp et al. (2013) reported that cell phone use was significantly $(p=0.047)$ and negatively $(\beta=-0.25)$ related to cardio respiratory fitness independent of sex, self-efficacy and percent fat. 5) Decrease in life satisfaction (Lepp et al., 2014). Lepp et al. (2014) investigated the relationship between total cell phone use $(\mathrm{N}=496)$ and texting $(\mathrm{N}=490)$ on Satisfaction with Life (SWL) in a large sample of college students. Cell phone use/texting was negatively related to Academic Performance and positively related to anxiety. 6) The attitude towards mobile phone as a social status symbol reduced life satisfaction of Chinese adolescents (Xue et al., 2016). 7) Mobile phone use after lights out increased anxiety, depression, tiredness and psychological stress and longer sleep latency, worse sleep efficiency, more sleep disturbance and more daytime dysfunction in Belgium Flemish adults aged 19 - 94 years old (Saling \& Heire, 2016). 8) The electromagnetic radiofrequency radiation (EMRF) from mobile phone may cause adverse health effects on human. Mobile phone usage while driving can cause road traffic collisions and motor vehicle crashes (Velmurugan, 2017). 
Light conditions are most effective zeitgeber for human circadian clock (Wada et al., 2013). Exposure to sunlight or lighting by mobile phones in the morning is possible to trigger synthesis of serotonin in the pineal body (Rosenthal et al., 1997; Wada et al., 2013). This action is hypothesized to occur mainly in the morning, because the amount of tryptophan consumed with supper has neither significant effects on Moriningness-Eveningness (M-E) scores nor an effect on sleep habits, as shown by another study on young Japanese children performed in 2005 (Harada et al., 2012). Melatonin is synthesized in the pineal body of the hypothalamic area from serotonin and secreted at night. Melatonin concentration in the serum could be well be positively correlated with that in the saliva (Nowak et al., 1987; Laakso et al., 1987; Nagtegaal, 1998). Secretion of melatonin exhibits circadian rhythms and could be suppressed by medium or bright light (Aoki et al., 1998; Burgess et al., 2001; Kubota et al., 2002; Harada, 2004; Higuchi et al., 2014) especially blue lights with $460 \mathrm{~nm}$ as peak wave length which can be well absorbed by melanopsin in the neuro-ganglia cells in retina (Joyce et al., 2015; Meijden et al., 2015). Even lights emitted from display of mobile phones can attenuate melanin expression duration at night (Gooley et al., 2011). Evening lightings have been shown to affect circadian rhythms (Kuller et al., 2002; Middleton et al., 2002) in human. In mice, evening lights affect mental health (Fonken et al., 2009). Tryptophan intake at breakfast might be effective for the onset and offset of sleep in young children based on a questionnaire study (Harada et al., 2007). Moreover, young children exposed to sunlight for more than 30 minutes after having sources of protein at breakfast might be more morning-typed than those exposed for less than 30 minutes (Nakade et al., 2009) also based on another questionnaire study.

Mobile phone use means the exposure to blue lights in several times of day for children and students and the effect of this light may be considered as an effective item for controlling their circadian issues currently and in the near future.

There have been few studies to clarify the relationship between circadian typology and the usage of the mobile phone (especially current common items in Japan: smart phone). This study aims to clarify the relationship of their mobile phone usage to their diurnal life in Japanese students aged 18 - 30 years old.

\section{Methods}

\subsection{Participants and Instruments}

The integrated questionnaire was administered in 2015 to 555 students (females: 248; males: 307) attending university and medical training schools (for medical nurses and physical therapists) located in Kochi City $\left(33^{\circ} \mathrm{N}, 133^{\circ} \mathrm{E}\right)$. More than $98 \%$ of them answered the questionnaire, and more than $98 \%$ of the questionnaires distributed were analyzed statistically. The questionnaire included, 1) Diurnal type score questionnaire (DTSQ) Torsval and Åkerstedt (1980) constructed, 2) Questions on sleep habit (bedtime, wake-up time, sleep hours of both weekdays and weekend), 3) Questions on mental health (irritation, anger, out of controlling emotion, depression), 4) Questions on the usage of mobile 
phones (types of the phones, frequency to use, day of time for usage, usage duration per one time) (Table 1).

\subsection{Statistic Analysis}

Results of this study were analyzed with statistical software as SPSS 12 version (12.0 J for Windows; SPSS Inc., Chicago, IL, USA). $\chi^{2}$-test was used for categorized variables $\mathrm{x}$ categorized variables. Mann-Whitney $\mathrm{U}$-test for categorized variables $\mathrm{x}$ ratio scale variables. Mental Health Index was expressed as sum of scales on 4 questions on mental health (irritation, anger, out of controlling emotion, depression). Scores of the mental health index were distributed from 4 (worst) to 16 (best) points.

\subsection{Ethic Treatment}

The study followed the guidelines established by the Chronobiology International Journal for the conduct of research on human subjects (Portaluppi et al., 2010). Before administrating the questionnaires, each participant was given a written explanation that detailed the concepts and purposes of the study and stated that their answers would be used only for academic purposes. After the above explanation, all participants agreed completely with the proposal. The study was also permitted by the ethic committee in the Laboratory of Environmental Physiology, Graduate School of Integrated Arts and Sciences, Kochi University which carried out an ethical inspection of the contents of the questionnaire.

\section{Results}

Duration of mobile phone usage ranged from 5 - 10 minutes per day to more

Table 1. Questions on usage of mobile phones in Japanese students aged 18 - 30 years old.

\begin{tabular}{|c|c|c|c|}
\hline \multicolumn{4}{|c|}{ Q1: How frequently do you use mobile phone per week? } \\
\hline 1) every day & 2) 4 - 5 times & 3) 2 - 3 times & 4) 0 - 1 time \\
\hline \multicolumn{4}{|c|}{ Q2: What time do you mainly use mobile phones in weekdays? (multiple answers available) } \\
\hline 1) $6: 00 \sim 9: 00$ & 2) $9: 00 \sim 12: 00$ & 3) $12: 00 \sim 15: 00$ & 4) $15: 00 \sim 18: 00$ \\
\hline 5) $18: 00 \sim 21: 00$ & 6) $21: 00 \sim 24: 00$ & 7) $24: 00 \sim 3: 00$ & 8) $3: 00 \sim 6: 00$ \\
\hline \multicolumn{4}{|c|}{$\begin{array}{l}\text { Q3-1: On the usage of mobile phone between bedtime to wake-up time, } \\
\text { where do you put your mobile phone when you go to bed? }\end{array}$} \\
\hline \multirow{2}{*}{\multicolumn{2}{|c|}{$\begin{array}{l}\text { 1) in the bed (e.g. near to head) } \\
\text { 3) other rooms than bed room }\end{array}$}} & \multirow{2}{*}{\multicolumn{2}{|c|}{ 2) far from the bed but inside bedroom }} \\
\hline & & & \\
\hline \multicolumn{4}{|c|}{$\begin{array}{l}\text { Q3-2: When you are going to fall in sleep in the bed and phone from mobile phone rings } \\
\text { (including mail, LINE and so on), how do you respond to it? }\end{array}$} \\
\hline \multirow{2}{*}{\multicolumn{2}{|c|}{$\begin{array}{l}\text { 1) Respond to it soon, } \\
\text { 3) No attention but sleep }\end{array}$}} & \multirow{2}{*}{\multicolumn{2}{|c|}{ 2) Check it but no response, }} \\
\hline & & & \\
\hline \multicolumn{4}{|c|}{ Q4: How long per one usage do you use mobile phone in weekdays? } \\
\hline 1) within & 2) $10 \sim 30 \mathrm{~min}$ & 3) $30 \min \sim 1 \mathrm{~h}$ & 4) $>1 \mathrm{~h}$ \\
\hline 5) 1 - 2 hours & 6) 3 hours or more & & \\
\hline
\end{tabular}


than 6 hours. One hundred and eighteen students of 535 ones in total used mobile phone for more than 6 hours per one day (Table 2). About eighty five percent of students kept their mobile phones in their bed side (Table 3). Minutes or

Table 2. Duration of the usage of mobile phone (smart phone) and sleep habit and mental health.

\begin{tabular}{|c|c|c|c|c|c|}
\hline Duration of mobile phone & Wakeup time & Sleep hours & Sleep quality & DTS & Mental health \\
\hline $5-10(\min )$ & $\begin{array}{c}7.16 \pm 0.46 \\
(106)\end{array}$ & $\begin{array}{c}6.93 \pm 0.96 \\
(106)\end{array}$ & $\begin{array}{c}1.82 \pm 0.41 \\
(106)\end{array}$ & $\begin{array}{c}15.64 \pm 4.07 \\
(104)\end{array}$ & $\begin{array}{c}12.45 \pm 2.30 \\
(105)\end{array}$ \\
\hline $10-30$ & $\begin{array}{c}7.16 \pm 0.48 \\
(114)\end{array}$ & $\begin{array}{c}6.96 \pm 0.88 \\
(114)\end{array}$ & $\begin{array}{c}1.89 \pm 0.87 \\
(100)\end{array}$ & $\begin{array}{c}15.45 \pm 3.15 \\
(114)\end{array}$ & $\begin{array}{c}12.45 \pm 1.90 \\
(114)\end{array}$ \\
\hline $30-60$ & $\begin{array}{c}7.19 \pm 0.52 \\
(60)\end{array}$ & $\begin{array}{c}6.84 \pm 1.34 \\
(60)\end{array}$ & $\begin{array}{c}1.92 \pm 0.27 \\
(52)\end{array}$ & $\begin{array}{c}14.45 \pm 4.54 \\
(60)\end{array}$ & $\begin{array}{c}12.21 \pm 0.60 \\
(60)\end{array}$ \\
\hline $1-5$ (hour) & $\begin{array}{c}7.14 \pm 0.45 \\
(73)\end{array}$ & $\begin{array}{c}6.91 \pm 1.04 \\
(73)\end{array}$ & $\begin{array}{c}1.87 \pm 0.34 \\
(73)\end{array}$ & $\begin{array}{c}15.26 \pm 3.54 \\
(74)\end{array}$ & $\begin{array}{c}12.12 \pm 0.17 \\
\quad(73)\end{array}$ \\
\hline $5-6$ & $\begin{array}{c}7.03 \pm 0.59 \\
(64)\end{array}$ & $\begin{array}{c}6.94 \pm 1.05 \\
(63)\end{array}$ & $\begin{array}{c}1.93 \pm 0.26 \\
(57)\end{array}$ & $\begin{array}{c}16.05 \pm 3.21 \\
(61)\end{array}$ & $\begin{array}{c}11.21 \pm 3.63 \\
(64)\end{array}$ \\
\hline$>6$ & $\begin{array}{c}7.27 \pm 0.45 \\
(118)\end{array}$ & $\begin{array}{c}6.86 \pm 1.18 \\
(117)\end{array}$ & $\begin{array}{c}1.97 \pm 0.26 \\
(116)\end{array}$ & $\begin{array}{c}14.87 \pm 3.47 \\
(119)\end{array}$ & $\begin{array}{c}12.15 \pm 0.48 \\
(121)\end{array}$ \\
\hline Total & $\begin{array}{c}7.17 \pm 0.49 \\
(535)\end{array}$ & $\begin{array}{c}6.91 \pm 1.06 \\
(533)\end{array}$ & $\begin{array}{c}1.90 \pm 0.33 \\
(464)\end{array}$ & $\begin{array}{c}15.37 \pm 3.65 \\
(531)\end{array}$ & $\begin{array}{c}12.21 \pm 2.27 \\
(538)\end{array}$ \\
\hline \multicolumn{6}{|c|}{ Kruskal-Wallis test } \\
\hline & Wakeup time & Sleep hours & Sleep quality & DTS & Mental health \\
\hline$\chi^{2}$-value & 8.358 & 1.932 & 8.991 & 4.296 & 8.860 \\
\hline $\mathrm{df}$ & 5 & 5 & 5 & 5 & 5 \\
\hline$p$ value & 0.138 & 0.858 & 0.109 & 0.508 & 0.115 \\
\hline
\end{tabular}

Table 3. Place of their own mobile phones (smart phones) when they sleep and sleep habit, circadian typology (DTS: The Diurnal Type Scale) and mental health.

\begin{tabular}{cccccc}
\hline Place of mobile phone & Wakeup time & Sleep hours & Sleep quality & DTS & Mental health \\
\hline Bed side & $7.20 \pm 0.48$ & $6.88 \pm 1.03$ & $1.91 \pm 0.32$ & $15.06 \pm 3.59$ & $12.13 \pm 2.30$ \\
& $(448)$ & $(448)$ & $(385)$ & $(446)$ & $(450)$ \\
Far from bed & $7.03 \pm 0.53$ & $7.08 \pm 1.19$ & $1.88 \pm 0.37$ & $15.45 \pm 3.15$ & $17.09 \pm 3.41$ \\
& $(81)$ & $(80)$ & $(73)$ & $(80)$ & $(83)$ \\
Different room & $6.92 \pm 0.25$ & $6.56 \pm 1.06$ & $1.75 \pm 0.46$ & $15.13 \pm 3.80$ & $12.63 \pm 2.00$ \\
& $(8)$ & $(8)$ & $(8)$ & $(8)$ & $(8)$ \\
Total & $7.17 \pm 0.49$ & $6.91 \pm 1.06$ & $1.90 \pm 0.33$ & $15.36 \pm 3.64$ & $12.22 \pm 2.28$ \\
& $(537)$ & $(535)$ & $(466)$ & $(534)$ & $(541)$ \\
& \multicolumn{7}{c}{ Kruskal-Wallis test } & & \\
\hline$\chi^{2}$-value & 11.334 & 2.943 & 7.598 & 11.334 & 3.113 \\
df & 2 & 2 & 2 & 2 & 2 \\
$p$ value & $0.003^{* *}$ & 0.230 & $0.022^{*}$ & $<0.001^{* * *}$ & 0.211 \\
\hline & Wakeup time & Sleep hours & Sleep quality & DTS & Mental health \\
\hline & & & & &
\end{tabular}

*: $0.01<p<0.05 ;{ }^{* *}: 0.001<p<0.01 ;{ }^{* *}: p<0.001$. 
hours per one usage of mobile phone had no significant effects on the diurnal type scale scores (Kruskall-Wallis test: $\mathrm{z}=4.296, \mathrm{df}=5, p=0.508$ ) and on bedtime in weekdays $(\mathrm{z}=0.705, \mathrm{df}=5, p=0.983)$ (Table 2), whereas the duration of usage tended to relate with later wake-up time $(\mathrm{z}=8.358, \mathrm{df}=5, p=0.138)$, worse quality of sleep $(\mathrm{z}=8.991, \mathrm{df}=5, p=0.109)$ (Table 2$)$, and worse mental health $(\mathrm{z}=8.960, \mathrm{df}=5, p=0.105)$ (Table 2) (Figure 1). Students who put their own mobile phone into bed side showed significantly later wake-up time $(\mathrm{z}=$ $11.334, \mathrm{z}=2, p=0.003$ ) (Figure 2), more evening-typed ( $\mathrm{z}=21.216, \mathrm{df}=2, p<$ $0.001)$ and worse quality of sleep $(\mathrm{z}=7.598, \mathrm{df}=2, p=0.022)$ than those who put them far from their beds (Table 3 ). However, the place of mobile phones during night sleep had no significant effects on sleep hours (Table 3). Students who responded calls during night sleep waked up 7:18 on average, whereas ones who had no attention to calls did it on 6:42 on average (Figure 3). Students who responded calls during night sleep or check the calls without responding showed

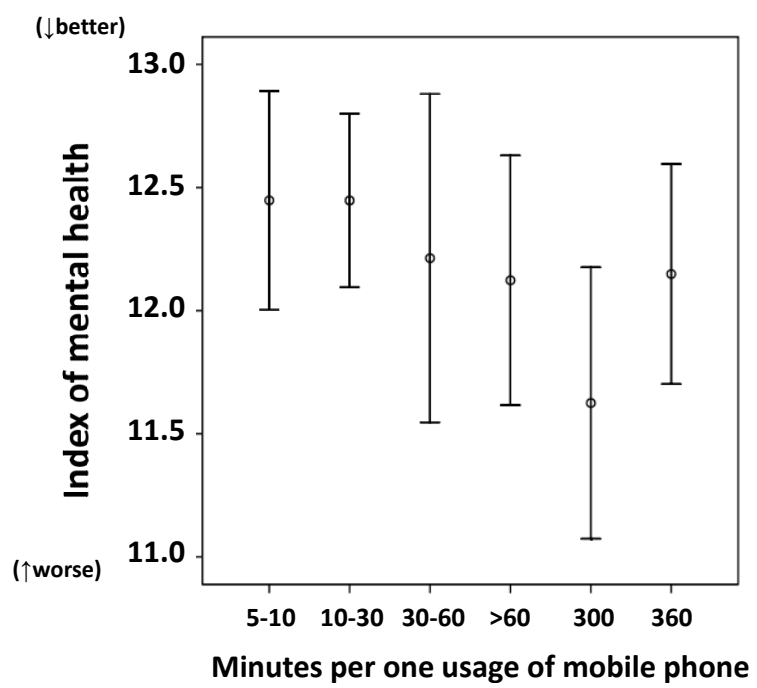

Figure 1. Relationship between duration per once of mobile phone use and mental health of Japanese students aged $18-30$.

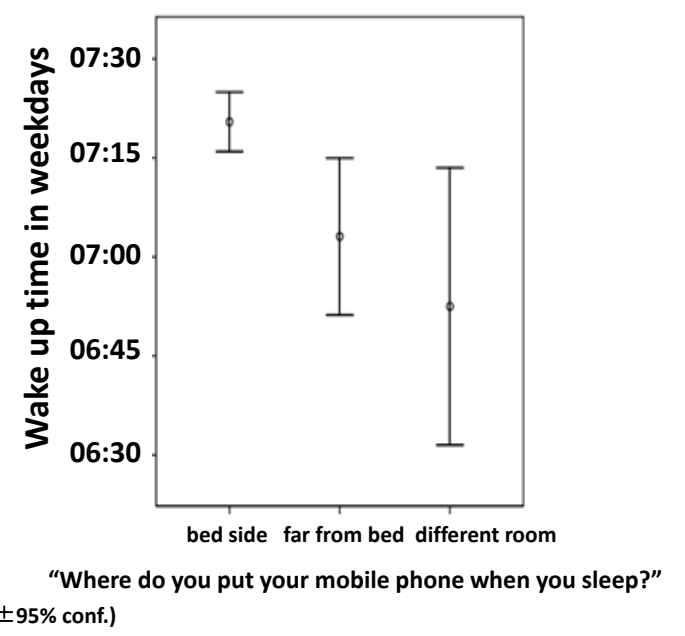

(Mean $\pm 95 \%$ conf.)

Figure 2. Place of mobile phone when they sleep and wake-up time in weekdays of Japanese students aged 18 - 30. 
14.7 - 14.9 on average of Diurnal Type Scale Scores, whereas those who had no attention to calls showed 16.3 (Figure 4). Students who respond or check calls during night sleep showed significantly later wake-up time (Figure 3 ) and significantly more evening-typed life (Figure 4) (Table 4).

(e.g. 07:44 means 7 hours 44 minutes)

(Mean $\pm 95 \%$ conf.)

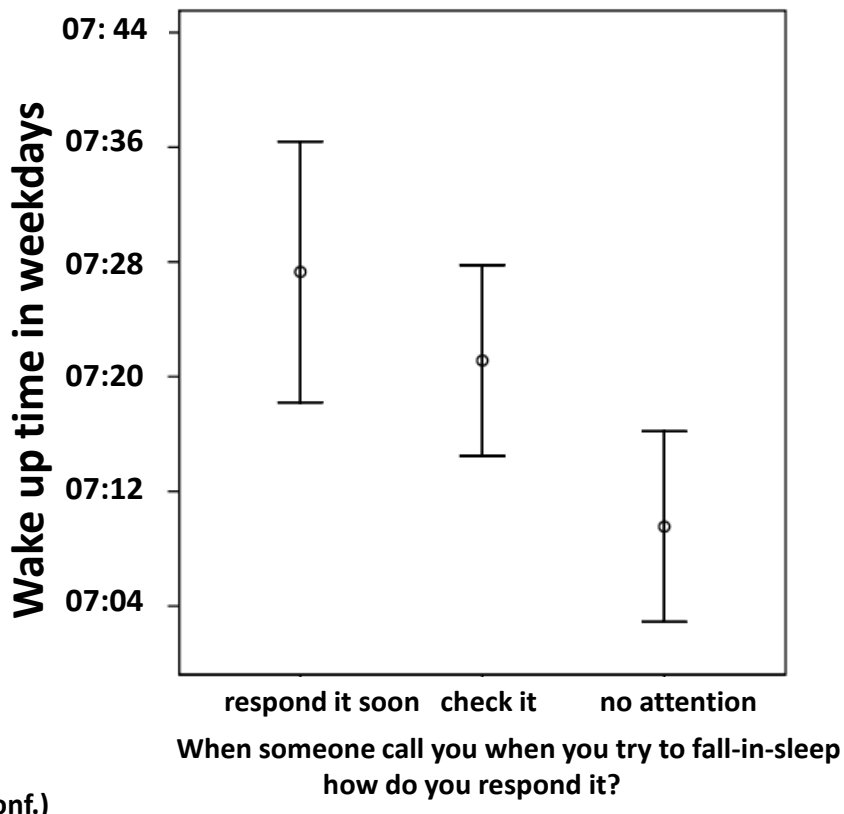

Figure 3. How they respond to call during night sleep and wake up time in weekdays of Japanese students aged 18 - 30 .

( $\uparrow$ Morning-typed)

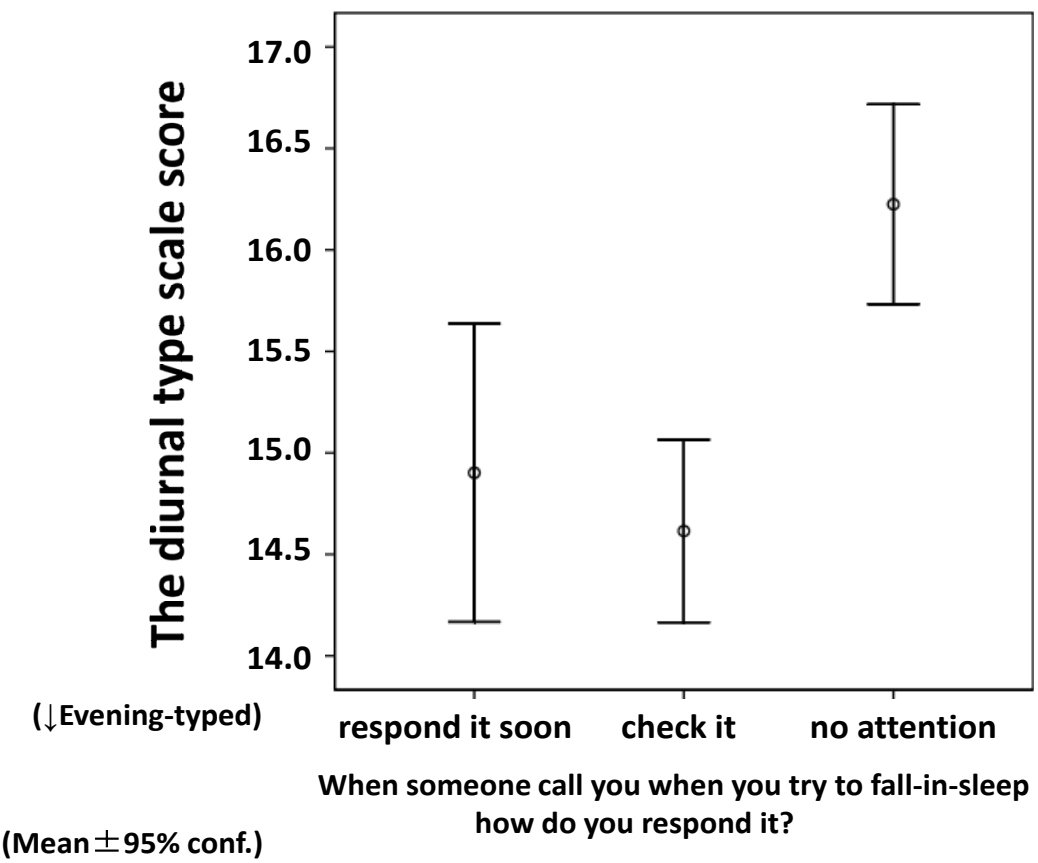

Figure 4. How they respond to call during night sleep and the circadian typology of Japanese students aged 18 - 30. 
Table 4. How they respond to call during night sleep and sleep habit, circadian typology (DTS: The Diurnal Type Scale) and mental health.

\begin{tabular}{cccccc}
\hline $\begin{array}{c}\text { How they respond } \\
\text { mid-night call }\end{array}$ & Wakeup time & Sleep hours & Sleep quality & DTS & Mental health \\
\hline Respond it soon & $7.27 \pm 0.45$ & $7.07 \pm 1.02$ & $1.91 \pm 0.32$ & $14.90 \pm 3.74$ & $12.07 \pm 2.20$ \\
& $(100)$ & $(99)$ & $(89)$ & $(104)$ & $(101)$ \\
Check it & $7.21 \pm 0.48$ & $6.79 \pm 1.02$ & $1.95 \pm 0.25$ & $14.62 \pm 3.23$ & $12.14 \pm 2.30$ \\
& $(205)$ & $(205)$ & $(174)$ & $(200)$ & $(205)$ \\
No attention & $7.09 \pm 0.50$ & $6.95 \pm 1.11$ & $1.86 \pm 0.39$ & $16.22 \pm 3.76$ & $12.35 \pm 2.31$ \\
& $(227)$ & $(226)$ & $(200)$ & $(227)$ & $(230)$ \\
Total & $7.17 \pm 0.49$ & $6.91 \pm 1.06$ & $1.90 \pm 0.33$ & $15.36 \pm 3.64$ & $12.22 \pm 2.28$ \\
& $(537)$ & $(530)$ & $(436)$ & $(529)$ & $(536)$ \\
& & Kruskal-Wallis test & & \\
\hline$\chi^{2}$-value & 12.968 & 6.119 & 2.031 & 21.796 & 2.314 \\
df & 2 & 2 & 2 & 2 & 2 \\
$p$ value & $0.002^{* *}$ & $0.045^{*}$ & 0.362 & $<0.001^{* * *}$ & 0.314 \\
\hline
\end{tabular}

${ }^{*}: 0.01<p<0.05 ;{ }^{* *}: 0.001<p<0.01 ;{ }^{* *}: p<0.001$.

\section{Discussion}

Most of Japanese students aged 18 - 30 years used their own smart phone every day on average 3.44 hours per day and their lives seem to depend on their mobile phones. The duration of smart phone usage ranges from 5 - 10 min into 6 hours, currently. Over-use of the smart phone especially on bed at night may, not only, make Japanese students evening-typed, but also make sleep hours shorter and mental health worse. Exposure to short-wave light including lights with wavelengths of $460 \mathrm{~nm}$ at night seems to make their circadian clock phase delayed and also to suppress melatonin synthesis (Hashimoto et al., 1996; Zeitzer et al., 2000; Wright \& Lack, 2001; Harada, 2004; Kayumov et al., 2005; Yasukouchi et al., 2007; Wada et al., 2013; Higuchi et al., 2014). Also long time exposure to lights from the display might affect central nervous system in human through other routes rather than affecting the circadian system.

Moreover, placing their own smart phone in bedside and quick response and checking the phone call even in the bedtime and/or mid night seem to make them evening-typed and their sleep hours shorter. Such psychological pressure for using smartphone for the communication with their colleagues might become strong zeitgeber to delay the phase of their circadian clock. Li et al. (2015) also reported that usage of cell phones at bed time can cause lower quality of sleep of undergraduate students. It was recommended for undergraduate students to avoid the usage of mobile (smart) phones at bed time and during sleep for keeping their sleep health.

The over use of their smart phone especially in night time would make their circadian typology evening typed through the exposure to lights from the display of the phone (including the light with $460 \mathrm{~nm}$ length which is main wave length 
for absorption of melanopsin as a key light sensor to control circadian clock phase and also plasma melatonin concentration of humans: Roecklein et al., 2013) or a psychological effects. The over use of the phone would be avoided for promoting the mental health and sleep health of Japanese students aged $18-30$ years. As limitation of this study, the participants number of questionnaire study was about 500 and more than thousand number will be powerful for the near future. Also the effects of mobile phone use needs a sophisticated design of experiments like as an intervention study also near future.

\section{Acknowledgements}

Thanks should be due to all the participants in this study. The following financial supports have been supplied to this study: 1) JSPS fund (Foundation No. 22370089) (To T. Harada: 2010-2013); 2) Fund from J-Milk "Meals and Education" (To T. Harada: 2013-2014); 3) Fund from J-Mild "Research Study to Promote Health by Milk and related foods" (To T. Harada: 2016-2017). 5) JSPS fund, (Foundation No. JP 16K01871) (To H. Takeuchi: 2016-2019).

\section{References}

Aoki, H., Yamada, N., Ozeki. Y., Yamane, H., \& Kato, N. (1998). Minimum Light Intensity Required to Suppress Nocturnal Melatonin Concentration in Human Saliva. Neuroscience Letters, 252, 91-94.

Beranuy, M., Oberst, U., Carbonell, X., \& Chamarro, A. (2009). Problematic Internet and Mobile Phone Use and Clinical Symptoms in College Students: The Role of Emotional Intelligence. Computers in Human Behavior, 25, 1182-1187.

Burgess, H. J., Sletten, T., Savic, N., Gilbert, S. S., \& Dawson, D. (2001). Effects of Bright Light and Melatonin on Sleep Propensity, Temperature, and Cardiac Activity at Night. Journal of Applied Physiology, 91, 1214-1222.

Exelmans, L., \& Van den Bulk, J. (2016). Bedtime Mobile Phone Use and Sleep in Adults. Social Science \& Medicine, 148, 93-101.

Fonken, L. K., Finv, M. S., Walton, J. C., Weil, Z. M., Workman, J. L., Ross, J., \& Nelson, R. J. (2009). Influence of Light at Night on Murine Anziety and Depressive-Like Responses. Behavior and Brain Research, 205, 349-354.

Fossum, I. N., Nordness, L. T., Storemark, S. S., Bjorvatn, B., \& Pallesen, S. (2014). The Association between Use of Electronic Media in Bed before Going to Sleep and Insomnia Symptoms, Daytime Sleepiness, Morningness, and Chronotype. Behavioral Sleep Medicine, 12, 343-357. https://doi.org/10.1080/15402002.2013.819468

Gooley, J. J., Chamberiain, K., Smith, K. A., Khalsa, S. B. S., Rajaratnam, S. M. W., Reen, E. V., Zeitzer, J. M., Czeisler, C. A., \& Lockley, S. W. (2011). Exposure to Room Light before Bedtime Suppresses Melatonin Onset and Shortens Melatonin Duration in $\mathrm{Hu}$ mans. Journal of Clinical and Endocrine Metabolism, 96, E463- E472. https://doi.org/10.1210/jc.2010-2098

Harada, T. (2004). Effects of Evening Light Conditions on Salivary Melatonin of Japanese Junior High School Students. Journal of Circadian Rhythms, 2, 1-5. https://doi.org/10.1186/1740-3391-2-4

Harada, T., Hirotani, M., Maeda, M., Nomura, H., \& Takeuchi, H. (2007). Correlation between Breakfast Tryptophan Content and Morningness-Eveningness in Japanese Infants and Students Aged 0-15 Yrs. Journal of Physiological Anthropology, 26, 201-207. 
https://doi.org/10.2114/jpa2.26.201

Harada, T., Nakade, M., Wada, K., Kondo, A., Maeda, M., Noji, T., \& Takeuchi, H. (2012). Mental Health of Children from a Chronobiological and Epidemiological Point of View. In O. V. Rijeka (Ed.), Essential Notes in Psychiatry (Chapter 22, pp. 439-458). Rijeka: Intech. https://doi.org/10.5772/38801

Hashimoto, S., Nakamura, K., Honma, S., Tokura, H., \& Honma, K. (1996). Melatonin Rhythm Is Not Shifted by Lights That Suppress Nocturnal Melatonin in Humans under Entrainment. American Journal of Physiology, 270, R1073-R1077.

Higuchi, S., Nagafuchi, Y., Lee, S.-I., \& Harada, T. (2014). Influence of Light at Night on Melatonin Suppression in Children. Journal of Clinical Endocrinology and Metabolism, 99, 3298-3303. https://doi.org/10.1210/jc.2014-1629

Joyce, D. S., Feigl, B., Cao, B., \& Zele, A. J. (2015). Temporal Characteristics of Melanopsin Inputs to the Human Pupil Light Reflex. Vision Research, 107, 58-66.

Kayumov, L., Casper, R. F., Hawa, R. J., Perelman, B., Chung, S. A., Sokalsky, S., \& Shapiro, C. M. (2005). Blocking Low-Wavelength Light Prevents Nocturnal Melatonin Suppression with No Adverse Effect on Performance during Simulated Shift Work. Journal of Clinical Endocrinology and Metabolism, 90, 2755-2761. https://doi.org/10.1210/jc.2004-2062

Kubota, T., Uchiyama, M., Suzuki, H., Shibui, K., Kim, K., Tan, X., Tagaya, H., Okawa, M., \& Inoue, S. (2002). Effects of Nocturnal Bright Light on Saliva Melatonin, Core Body Temperature and Sleep Propensity Rhythms in Human Subjects. Neuroscience Research, 42, 115-122.

Kuller, R. (2002). The Influence of Light on Circadian Rhythms in Humans. Journal of Physiological Anthropology, 21, 87-91. https://doi.org/10.2114/jpa.21.87

Laakso, M. L., Porkka-Keiskanen, T., Alila, A., Stenberg, D., \& Johansson, G. (1987). Correlation between Salivary and Serum Melatonin: Dependence on Serum Melatonin Levels. Journal of Pineal Research, 9, 39-50. https://doi.org/10.1111/j.1600-079X.1990.tb00692.x

Lepp, A., Barkley, J. E., Sanders, G. J., Rebold, M., \& Gates, P. (2013). The Relationship between Cell Phone Use. International Journal of Behavioral Nutrition and Physical Activity, 10, 79. https://doi.org/10.1186/1479-5868-10-79

Lepp, A., Barkley, J., \& Karpinski, A. (2014). The Relationship between Cell Phone Use, Academic Performance, Anxiety, and Satisfaction with Life in College Students. Computers in Human Behavior, 31, 343-350.

Li, L., Lepp, A., \& Barkley, J. E. (2015). Locus of Control and Cell Phone Use: Implications for Sleep Quality, Academic Performance, and Subjective Well-Being. Computers in Human Behavior, 52, 450-457.

Meijden, W., Van der, W., Te Lindert, B. H. W., Bijlenga, D., Coppens, J. E., Gomez-Herrero, G., Bruijel, J., Kooij, J. J. S., Cajochen, C., Bourgin, P., \& Van Someren, E. J. W. (2015). Post-Illumination Pupil Response after Blue Light: Reliability of Optimized Melanopsin-Based Photo Transduction Assessment. Experimental Eye Research, 139, 73-80.

Middleton, B., Stone, B. M., \& Arendt, J. (2002). Human Circadian Phase in 12:12h, 200: $<8$ lux and 1000:<8 lux Light-Dark Cycles, without Scheduled Sleep or Activity. Neuroscience Letters, 329, 41-44.

Nakade, M., Takeuchi, H., Taniwaki, N., Noji, T., \& Harada, T. (2009). An Integrated Effect of Protein Intake at Breakfast and Morning Exposure to Sunlight on the Circadian Typology in Japanese Infants Aged 2-6 Years. Journal of Physiological Anthropology, 28, 239-245. https://doi.org/10.2114/jpa2.28.239 
Nagtegaal, E., Peeters, T., Swart, W., Smits, M., Kerkhof, G., \& Van der Meer, G. (1998). Correlation between Concentrations of Melatonin in Saliva and Serum in Patients with Delayed Sleep Phase Syndrome. Therapeutic Drug Monitoring, 20, 181-183. https://doi.org/10.1097/00007691-199804000-00008

Nowak, R., Mcmillen, I. C., \& Redman, J. (1987). The Correlation between Serum and Salivary Melatonin Concentrations and Urinary 6-Hydroxymelatonin Sulphate Excretion Rates: Two NN-Invasive Techniques for Monitoring Human Circadian Rhythmicity. Clinical Endocrinology, 27, 445-452. https://doi.org/10.1111/j.1365-2265.1987.tb01172.x

Portaluppi, F., Smolensky, M. H., \& Touitou, Y. (2010). Effects and Methods for Biological Rhythm Research on Animals and Human Beings. Chronobiology International, 27, 1911-1929. https://doi.org/10.3109/07420528.2010.516381

Rebold, M. J., Lepp, A., Sanders, G. J., \& Barkley, J. (2015). The Impact of Cell Phone Use on the Intensity and Liking of a Bout of Treadmill Exercise. PLOS ONE, 10, e0125029. https://doi.org/10.1371/journal.pone.0125029

Roecklein, K. A., Wong, P. M., Miller, M. A., Donofry, S. D., Kamarck, M. L., \& Brainard, G. C. (2013). Melanopsis, Photosensitive Ganglion Cells, and Seasonal Affective Disorder. Neuroscience and Biobehavioral Reviews, 37, 229-239.

Rosenthal, N., Schwartz, P., Tumer, E., Nalm, S., Matthews, J., Hardin, T., Barnett, R., \& Wehr, T. (1997). The Psychobiology of SAD and the Mechanism of Action of Light Therapy. Biological Psychiatry, 42, 57S.

Saling, L. L., \& Haire, F. (2016). Are You Awake? Mobile Phone Use after Lights Out. Computers in Human Behavior, 64, 932-937.

Torsvall, M. D., \& Åkerstedt, T. A. (1980). A Diurnal Type Scale: Construction, Consistency and Validation in Shift Work. Scandinavian Journal of Work and Environmental Health, 6, 283-290. https://doi.org/10.5271/sjweh.2608

Velmurugan, M. S. (2017). Sustainable Perspectives on Energy Consumption, EMRF, Environment, Health and Accident Risks Associated with the Use of Mobile Phones. Renewable and Sustainable Energy Reviews, 67, 192-206.

Wada, K., Yata, S., Akimitsu, O., Krejci, M., Noji T., Nakade, M., Takeuchi, H., \& Harada, T. (2013). A Tryptophan-Rich Breakfast and Exposure to Light with Low Color Temperature at Night Improve Sleep and Salivary Melatonin Level in Japanese Students. Journal of Circadian Rhythms, 11, 4.

Wright, H. R., \& Lack, L. C. (2001). Effect of Light Wavelength on Suppression and Phase Delay of the Melatonin Rhythm. Chronobiology International, 18, 801-808. https://doi.org/10.1081/CBI-100107515

Xue, X., Zhao, F., Xie, J., \& Lei, L. (2016). Symbolization of Mobile Phone and Life Satisfaction among Adolescents in Rural Areas of China: Mediating of School-Related Relationships. Computers in Human Behavior, 64, 694-702.

Yasukouchi, A., Hazama, T., \& Kozaki, T. (2007). Variations in the Light-Induced Suppression of Nocturnal Melatonin with Special Reference to Variations in the Papillary Light Reflex in Humans. Journal of Physiological Anthropology, 26, 113-121. https://doi.org/10.2114/jpa2.26.113

Zeitzer, J. M., Dijk, D. J., Kronauer, R. E., Brown, E. N., \& Czeisler, C. A. (2000). Sensitivity of the Human Circadian Pacemaker to Nocturnal Light: Melatonin Phase Resetting and Suppression. Journal of Physiology, 526, 695-702.

https://doi.org/10.1111/j.1469-7793.2000.00695.x 
Submit or recommend next manuscript to SCIRP and we will provide best service for you:

Accepting pre-submission inquiries through Email, Facebook, LinkedIn, Twitter, etc. A wide selection of journals (inclusive of 9 subjects, more than 200 journals)

Providing 24-hour high-quality service

User-friendly online submission system

Fair and swift peer-review system

Efficient typesetting and proofreading procedure

Display of the result of downloads and visits, as well as the number of cited articles Maximum dissemination of your research work

Submit your manuscript at: http://papersubmission.scirp.org/

Or contact psych@scirp.org 